\title{
Herman Lent, Scientist and Citizen - II
}

\author{
JOSÉ JURBERG \\ Instituto Oswaldo Cruz, Laboratório Nacional e Internacional de Referência em Taxonomia de Triatomíneos, \\ Cx. Postal 926, Av. Brasil, 4365 - Manguinhos - 21040-900 Rio de Janeiro, RJ, Brasil
}

Brazil and Science lost a unique figure on July 7 , 2004, when Herman Lent died, at 93 years of age. Herman Lent was Emeritus Researcher of the Fundação Oswaldo Cruz, recipient of the Order of Scientific Merit in the category of Grã-Cruz in 2002, Member of Academia Brasileira de Ciências (Brazilian Academy of Sciences) and Lecturer and Researcher level 1A of Conselho Nacional de Desenvolvimento Científico e Tecnológico (CNPq - National Research Council of Brazil). His memory and reasoning remained intact up to the last, and he never left off discussing problems related to science and mainly to ethics in human behavior with his colleagues at the laboratory, which he frequented assiduously. Even in his last years.

Hunted politically, due to his political and ethical attitudes, he had his political and civil rights suspended by the military dictatorship that came into power in 1964, which led to his dismissal from the Instituto Oswaldo Cruz in 1970, one of the ten researchers who were forbidden to exercise any scientific or teaching activity there, besides being banned from frequenting Manguinhos library.

At the beginning of his career, he dedicated himself to helminthology and later on to entomology, investigating the vectors of Chagas' disease, a field in which he became a distinguished researcher and was acknowledged as one of the greatest triatomine specialists in the world, he published two hundred and forty scientific papers on this group of

E-mail: jjurberg@ @ioc.fiocruz.br vectors. Since 1979, when Herman Lent published a treaty on Taxonomy of Triatomines in collaboration with one of his colleagues, Petr Wygodzinsky, there has not been any publication in this field that does not cite this work, in which he described with rich morphological, chromatic, biological and geographical details the 115 species known at that time. He commented, with a note of bitterness, his sorrow for not having had it published in Portuguese, in Brazil, a work that consumed forty years of scientific effort.

Herman Lent was born on February 3, 1911, in the city of Rio de Janeiro, Brazil, the son of Hano and Anna Lent. His parents were Russian Jews, born in the city of Juromin in the Province of Plotz, who settled in Brazil to escape from the pogroms and ghettos of Eastern Europe. He attended high school at the Colégio Militar of Rio de Janeiro becoming a bachelor in Sciences and Letters in 1928, where he obtained the title of surveyor according to the rules of that school. He enrolled in the Faculdade de Medicina do Rio de Janeiro in 1929, where influenced by his professors Antônio Pacheco Leão, Hidalgo de Noronha and Olympio da Fonseca he directed his attention to studies on parasitology, already setting his feet on the path to Manguinhos. Herman married a co-worker, Maria Gregória, a chemical pharmacist of Paraguayan nationality, who had come to seek specialized training in Manguinhos and with whom he had two children, Roberto and Suzana Lent. 
In the conversations he maintained with the younger students in our laboratory, those who had just begun their careers, he talked about the difficulties he faced when he joined the Instituto Oswaldo Cruz. While still a novice, during his third year of Medicine, he gathered up his courage and went to Carlos Chagas, director of that Institute, with the aim of developing a work on xenodiagnosis. Chagas sent him to the "Curso de Aplicação" (training course) in Manguinhos, and from January, 1931 to December, 1932, he divided his time between the medical school and the Institute, from which he graduated on December 7, 1932.

The "Curso de Aplicação" included the subjects of physical chemistry, microscopy, immunology, bacteriology, mycology, protozoology, helminthology and entomology. Among his professors were some remarkable personalities, who showed him the pathway to his career: the helminthologist Lauro Travassos, the entomologist Ângelo Moreira da Costa Lima and the zoologist Adolpho Lutz. In order to attend the course and be able to follow the laboratory classes, he took with him his own microscope, a gift from his brother-in-law. At the same time that he graduated with an average of 8.65 in 10 , which paced him among the top three students in his class, he also completed the fourth year of medical school. He took his first steps in research as a volunteer in the Helminthology Department, under the guidance of Lauro Travassos.

From 1934 to 1935, he published sixteen scientific papers in collaboration with João Ferreira Teixeira de Freitas: fourteen on helminthology and two on the Psammolestes genus of the blood-sucking bug, being one of these in collaboration with Cezar Pinto.

From 1932 to October, 1936, he worked as a volunteer at the Institute, with no financial support. He was finally hired in 1936, and he worked there until April, 1970, when his political and civil rights were suspended by the military dictatorship. During the thirty-eight years that he worked there, he occupied many positions: researcher, head of the Division of Medical Zoology, professor, thesis ad- visor, head of his laboratory, curator, and editor of Memórias do Instituto Oswaldo Cruz, Revista Brasileira de Biologia, and Atas do Simpósio da Biota Amazônica.

In 1964, Francisco de Paula Rocha Lagoa assumed the direction of the Instituto Oswaldo Cruz. When he visited the Department of Entomology, on the second floor of Pavilhão Mourisco in Manguinhos (Rio de Janeiro), he met Herman Lent, who was at the time head of the Division of Medical Zoology. With him were Hugo de Souza Lopes, head of Entomology, and Sebastião José de Oliveira. As I had left the premises, I only heard the report of this meeting from Herman himself, early the next day. As the meeting developed, Rocha Lagoa expressed his wish, as director of Instituto Oswaldo Cruz, of administrating it according to procedures used at the Pentagon, an institution he had just visited as a student of the Escola Superior de Guerra (Brazilian War College). This caused a commotion in the room: Herman and everybody present agreed that there was no possibility of any kind of parallel between the two institutions: one was devoted to military activities in a rich country, while the other was a group of scientists in a poor country that was facing a historical moment of huge difficulties in all aspects. It never occurred to us that the destruction of the Department of Entomology was being decided at that very moment, and the meeting was soon adjourned. Six years later, when he took the Ministry of Health, Rocha Lagoa, now a Minister of State with a wide range of powers, managed to obtain the suspension of the political and civil rights, through AI-5, a type of law created at the dictatorship period, of ten researchers in Manguinhos, among them three of the four entomologists who made up the Department of Entomology.

Writing Herman's biography is almost the same as writing my own, since we shared so many important moments. In January, 1966, in the third attempt to detect subversive activities and to discover active communists at the Institute, all of us were called to testify at the Security Section of the Ministry of Health on Rio Branco Avenue, at the 
Clube de Engenharia. At 8 a.m. we were all waiting together in a small room, from which each one was summoned in turn. My turn came at 5 p.m., and I was asked two questions: Was I aware of any subversive activities going on in Manguinhos, and what was my opinion of the creation of the Ministry of Science. The time spent on the questions, the answers and the transcription of my testimony, which I was obliged to sign, was no more than one hour, a time that will be forever registered in my mind because of all the events that would take place in the Institute in 1970.

Later, I was told that at the conclusion of the investigation I was labeled "a recoverable communist", this probably being the reason why I had not been politically suspended, and which allowed the Department of Entomology to survive during a black period. In time it was able to regain its prominence as a field of research, and it now occupies the position of one of the most active departments at the Institute. The big turning point that made this possible was the transformation of Instituto Oswaldo Cruz into the Fundação Oswaldo Cruz, a foundation governed by the C.L.T., a collection of laws that regulate the relationship between employers and employees. That transformation allowed the hiring of new researchers in 1986, with the support of the government, and an increase in the salaries, which in fact was done by the first president of the Fundação Oswaldo Cruz, Vinicius da Fonseca, an economist appointed by the Minister of Planning, Reis Veloso.

From the very first years of my acquaintance with Herman it was clear to me that we shared the same goals and beliefs. I entered Manguinhos as his 24-year-old trainee, newly graduated and a single man, and he participated in my entire professional life and in much of my personal one. He was the bestman at my wedding, and I remained in his laboratory for 10 years while I was obtaining my master's degree he was my unofficial advisor, because as he had been suspended he was not allowed to have this position. At his request, his friend José Cândido de Melo Carvalho became my thesis advisor, and for a while I worked with Dr. Carvalho at the Museu Nacional, as I had been prohibited by Rocha Lagoa, now the Minister of Health, to publish with Herman. Later, I obtained my Ph.D. from Universidade Federal Rural do Rio de Janeiro, my doctoral dissertation was based on work we had published together, which led me to discover a new genus of blood-sucking bugs that I named Hermanlentia, as a tribute to him. It was not easy to create this denomination since his name had been immortalized long ago, due to the number of tributes already paid to him.

During the ten years we spent together in the laboratory, despite the fact he never showed any sign of religious feelings, I always reminded him of the Jewish holy days. Later, I used to invite him to join my family, with whom he had a great affinity, in those celebrations. When he was not able to come to our house, as health and age were beginning to weigh on him, I brought him samples of the typical Jewish dishes, which gave him much satisfaction as it reminded him of his childhood with his parents, who were religious people.

In 44 years of companionship, we spent ten years working together, eight of them in the same laboratory. One day I was surprised at the news that from that time on I would have my own laboratory, with all the necessary equipment. Two years later, at noon on April 1, 1970, Herman received the news that his political and civil rights. Had been suspended. Despite this, he came to work the next morning, but he was forced to leave his position as professor and researcher on April 3, when the director of Instituto Oswaldo Cruz called me to his office in order to ask me to tell Herman, Hugo de Souza Lopes and Sebastião José de Oliveira that that day would be the last on which they could enter the Campus of Manguinhos.

From 1964 to 1970, the Institute suffered a period of decadence: many technicians and researchers left, the physical installations deteriorated, the budget was being reduced every day and there was a Law on receiving any type of external support. Despite all this, some laboratories were able 
to remain productive right up until that day in April, when the weight of calculated destruction, made itself felt, with envy becoming externalized, and persecution triumphed. Many people thought that with the departure of the ten most eminent scientists a cycle of decadence and oppression had finally come to its end. That proved to be a mistake, as another cycle had just begun, bringing more pressure to bear on those who stayed at the Institute.

A few days after our colleagues had been expelled, that became very clear to us. We had been occupying all the second floor of the Pavilhão Mourisco (also known as Manguinhos Castle) with laboratories, meeting rooms, and the Entomological Collection installed in one of its biggest rooms, with an iron structure corresponding to three floors where more than one million species of the neotropical entomological fauna were deposited and preserved. When I was called to the office of the Director, Dr. Guilherme Lacorte, I had no idea of what he would tell me: not only had the Board decided to occupy the entire space in which we had our Department, but also that I and one of the technicians who survived the political suspensions, Mr. Orlando Vicente Ferreira, should prepare ourselves to be transferred to an old and abandoned building, the Hospital Evandro Chagas. I tried to argue by showing him the risk of transferring the contents of the Collection, consisting of hundreds of drawers holding insects impaled on pins, collections in alcohol, and boxes with insects stored inside envelopes waiting for the moment in which they would be set up together. Unfortunately, my arguments were in vain because all had already been decided, and whatever it the? cost, what was left of the Department should be transferred. All the trainees and students who were still there left at that very moment.

The removal was carried out by unqualified personnel of a commercial moving company. The results were terrible: dozens of drawers disappeared, hundreds of specimens broke and were disposed of by the movers, and some iron cabinets shattered after falling down from the second floor. The microscopes and the blood-sucking bug collec- tion were carried in my car on the technicians' laps and that was the sad end of this episode.

In 1986, when the political amnesty had already been granted, as the process of electing a new President of Fiocruz was about to begin, an opportunity arose to redeem the injustice perpetrated against the researchers who had had their political and civil rights suspended by the military dictatorship. In one of the public debates that took place in the auditorium of the Escola Nacional de Saúde Pública I asked one of the candidates, Sérgio Arouca, what would be his attitude, if e was elected, towards our colleagues who had had their political and civil rights suspended, and he promptly answered that it was for him a matter of honor to bring them back to the Institute. As Arouca was elected and kept his word, all the professors came back, except for Herman, who preferred to remain at Universidade Santa Úrsula, near the center of in the city, in gratitude for the courage shown by the Mother Superior of that university, when she welcomed him as a professor during one of the most repressive phases of the dictatorship. Although he did not accept the offer to return to his job at the Instituto Oswaldo Cruz, Herman agreed to become a Member of the Technical/Scientific Council (Conselho Técnico Científico da FIOCRUZ - CTC), and during the four years of the Arouca administration he actively participated in formulating its institutional policy and we again worked together as partners.

When Arouca asked the Instituto Oswaldo Cruz to appoint one of its researchers as secretary of the CTC, I presented myself as a candidate and was approved by its Deliberative Board. Among dozens of subjects discussed I put forward the question of the construction of a new library, since the total contents of the old library, which was on the third floor of Pavilhão Mourisco, had been transferred to the basement of the Instituto Nacional de Controle de Qualidade em Saúde (INCQS), which proved to be a very bad lodging since the basement used to be flooded during the period of the big summer rainfall, leading to the deterioration of books and magazines. Unfortunately, although everybody agreed that the 
library was a priority, we did not have the budget to build it.

In 1989, the World Bank and the Ministry of Health selected the Triatominae Laboratory to host the National and International Reference Laboratory for Triatominae Taxonomy, with financial resources and the possibility of hiring new researchers, besides establishing associations with foreign researchers and institutions, thus amplifying our lines of research. Through that agreement it was possible to hire technicians and researchers. A technician trained in the Technical Course on Parasite Biology of Instituto Oswaldo Cruz, Cleber Galvão, was the only one among those hired who went on to a career as researcher, and now, with Dayse S. Rocha, he makes up the fourth generation in the Laboratory. The Laboratory bought the Rodolfo Carcavallo Collection with fifteen thousand specimens of blood-sucking bugs, incorporating it into the Entomological Collection of the Instituto Oswaldo Cruz, and invited Professor Carcavallo to join its team, which was made possible by the support from CNPq. Professor Carcavallo brought to Brazil the Atlas dos Vetores da doença de Chagas nas Américas, a work conceived by him and partially accomplished at that time, which we published in three volumes, in a bilingual edition of 1217 pages at Editora FIOCRUZ, with Herman Lent as one of the editors.

In 1990, Dr. Hermann Gonçalves Schatzmayr took over as president, and I was invited to be his advisor, still in the position of secretary of the C.T.C. One day at the end of an afternoon, soon after the election, as we were talking about the existing difficulties and the priorities that should be worked out, I suggested once again, the goals, the building of the library. In a meeting of the C.T.C., this goal was approved, and I was appointed to preside over the group that would work in that project. There are some names that cannot be forgotten for their total support for it, such as Herman Lent, Carlos Chagas Filho and Henrique Leonel Lenzi, who later carried out the whole process. The library was built as a project of the architects of Manguinhos, with the active participation of the librarians in the creation of what is now a modern library and a source of pride to Brazilian Science. The memory of this struggle is preserved by Casa de Oswaldo Cruz, an institution created in 1986 by Dr. Sérgio Arouca, then President of FIOCRUZ, to preserve the history of Fundação Oswaldo Cruz and the memory of Brazilian Medicine.

The line of research initiated by Carlos Chagas in 1909 with the discovery of Chagas' disease lead to the creation of the Laboratório de Triatomíneos which had as its founders Arthur Neiva and Cezar Pinto in its first generation and Herman Lent in its second, who ran it from 1935 to 1970. In 1970, I took charge of the laboratory and despite all the obstacles we had to face we went on with our research. There was a period in when we were not allowed to publish, which did not prevent us from going on with our work - Herman at his home, and I at the laboratory - until the fall of Rocha Lagoa as Minister of Health, which made it possible to publish several papers that had already been written.

Under Herman Lent, the Laboratório de Triatomíneos had installed an insectarium and a collection of blood-sucking bugs, which provided the basic conditions for our work. When Herman was obliged to leave the Department, the future of all this was seriously jeopardized but, fortunately, we were able to cope with all the difficulties. In 1963 Herman had hired a young girl, Vanda Cunha, who was then only 13 years old, to help with the maintenance of the Entomological Collection, by pinning and labeling the insects. Her performance was so efficient that he began to add to her duties, including the task of helping to rear the blood-sucking bugs. Later se was put in charge of the maintenance of the insect colonies, a task that she has been performing for forty years. The insectarium has expanded into one of the most important in the Americas not only because of the diversity of species we maintain but also because of the amount of the material we have. Recently members of the laboratory dedicate to her a newly discovered species, Triatoma vandae Carcavallo, Jurberg, Rocha, Galvão, Noireau and Lent, 2001. 
The collection of blood-sucking bugs (dry material preserved in naphthalene), today designated as the Herman Lent Collection, holds more than nine thousand specimens. Besides receiving researchers, it is an open collection with a continuous growth, being a reference for triatomine specialists who want to elucidate problems related to taxonomy. At present the collection is being enriched by a parallel collection with material preserved in alcohol at $70^{\circ} \mathrm{GL}$ and another one with material preserved in a freezer.

Having written these words about some of the events of Herman's life and work have meant a lot to me, as I was able to remember fragments of my own professional life which ran in parallel to his during 44 years.

His scientific work can be evaluated by the reading of a bio-biography, recently published by me and by his collaborator, Claudia Portes Santos, and by another work, written by João Carlos Pinto Dias, which is part of a speech delivered as a tribute to Herman, in Revista Entomologia y Vectores 11(1).

His memory is forever preserved in the recollection of his deeds and in the minds and hearts of his friends.

\section{REFERENCES}

Carcavallo RU, Galíndez-Girón I, Jurberg J AND Lent H. 1998/1999. Atlas dos vetores da doença de Chagas nas Américas. 3 volumes. Rio de Janeiro: Editora Fiocruz. 1217 p.

Dias JCP. 2004. Herman Lent: Ciência, Vida e Exemplo. Entomol Vect 11: 1-18.
Ivanossevich A. 1991. Herman Lent, "O Cavaleiro de Manguinhos". Ciência Hoje 13(74): 62-67.

Jurberg J. 1993. Herman Lent. Rev Brasil Zool 10: $1-4$.

JuRberg J. 1993. Lista de publicações de Herman Lent. Rev Brasil Zool 10: 5-17.

JuRberg J. 1999. Noventa anos da descoberta da doença de Chagas e a criação do Centro de Referência em Taxonomia de Triatomíneos. Entomol Vect 6: $315-322$.

Jurberg C. 2002. Herman Lent, um obstinado empreendedor de Coleções. Sci Amer 1: 24-26.

JuRberg J AND SANTOS CP. 2004. História e bibliografia. Entomol Vect 11: 19-58.

Keller W. 1966. História do povo judeu. Edição Tertúlia do Livro Portugal. 536 p.

LENT H. 1947. Títulos e trabalhos científicos. Brochura apresentada para o concurso de Professor Catedrático de Zoologia e Parasitologia da Faculdade Nacional de Farmácia da Universidade do Brasil. Rio de Janeiro.

LENT H. 1972. O desenvolvimento da Entomologia no Instituto Oswaldo Cruz. Ciência e Cultura 24: 11921200.

Lent H. 1978. O massacre de Manguinhos. Rio de Janeiro: Avenir Editora. 69 p.

Lent H And Wygodzinsky P. 1979. Revision of the Triatominae (Hemiptera, Reduviidae) and their significance as vectors of Chagas' disease. Bull Amer Mus Nat History 163: 125-520. 